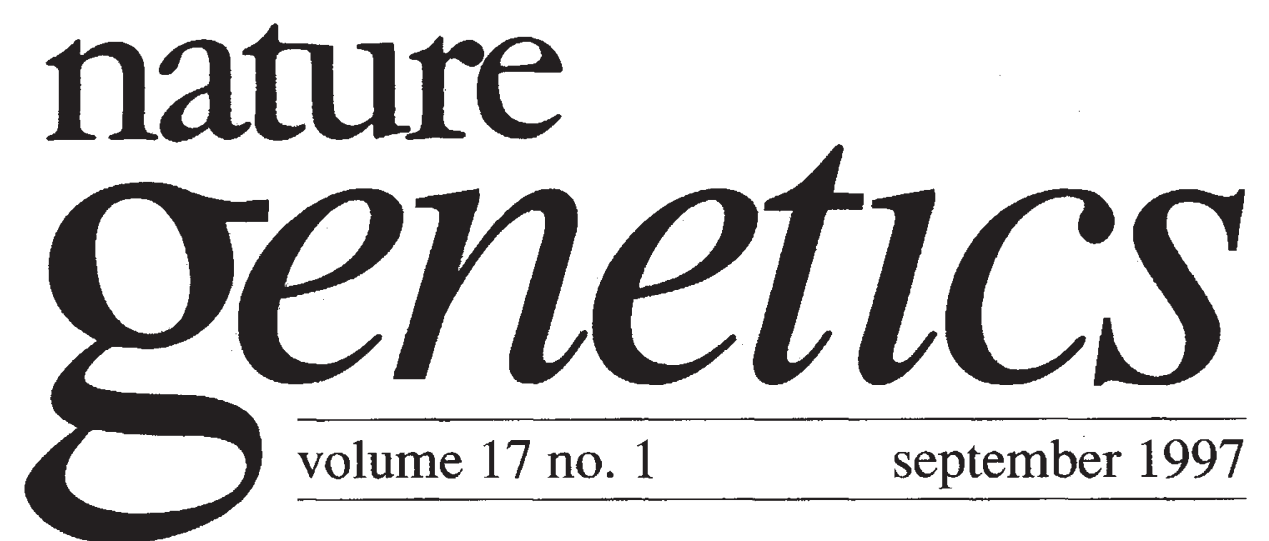

\title{
Holes in the Swiss legislation?
}

More than 100 years ago Swiss voters (then exclusively male) banned the slaughter of animals without prior anaesthesia in one of the country's first referenda. Now they are addressing the issue of genetic engineering by the same process. According to Switzerland's direct democracy rules, any proposal for a constitutional amendment securing the signatures of $1.5 \%$ of the population must be put to a vote in a national referendum. A simple majority supporting the proposal leads to its incorporation into the constitution (as long as the majority of the cantons-the regions -also vote in favour).

Several such proposals are being debated at any given time; in recent years, most of them have failed, due to insufficient interest at the signature stage. Public interest is enormous, however, for a recent proposal. More than 110,000 Swiss have signed the so-called Gen-Schutz Initiative (the gene protection initiative), founded in 1993 "to protect life and environment from genetic manipulation" and supported by more than 50 organizations; including the World Wide Fund for Nature, Greenpeace, female rights activists, Christian churches and the foundation for consumer protection. A vote is planned for June or September 1998.

Scepticism about technology is widespread in Western Europe, but shows clear regional differences; people in English-speaking and Latin countries seem to have a more pragmatic attitude, whereas the population of German-speaking and Scandinavian countries is more critical. Consistent with this, the majority of signatures supporting the Gen-Schutz-Initiative came from the German-speaking regions of Switzerland. Opponents of the initiative are convinced that a constitutional amendment regulating genetic technology is unnecessary. They argue that the Swiss constitution contains all the necessary legislation. The Swiss Parliament shares this attitude and rejected the initiative with a clear majority last year. On the other hand, activists argue that existing loopholes need to be closed, and that an absolute ban on certain specific practices is necessary.

A total ban on the use of transgenic animals and any field trials with genetically modified plants would cripple research and development in both academic institutions and industry. Denial of the right to patent genetically altered plants and animals or the procedures employed to generate them would affect biotechnology and pharmaceutical companies badly. Consequently, Swiss scientists as well as the pharmaceutical industry are in a state of alarm and have started to lobby for their cause. They have their work cut out-polls suggest that up to $75 \%$ of Swiss voters currently support the proposed amendment. 
Supporters of the initiative are busy campaigning using direct mailing, billboards and full-page advertisements in newspapers and magazines. As is so often the case when an issue is embraced by activist groups, much of the discussion is emotional in character and draws in unrelated topics such as the nuclear reactor accident in Chernobyl and 'mad cow' disease in Britain, suggesting that genetic technology is, if not responsible for these, at least bound to produce similar catastrophes.

The real issues underlying the debate, namely the potential benefits and risks of genetic technology, are complex. Explaining them to the average citizen is a daunting task, not least because no honest scientist would deny that potential risks exist and that the technology could be abused. The acceptance of genetic technology for medical purposes has steadily grown over the past ten years, both in Switzerland and elsewhere. Similarly, many people understand that in view of the huge costs associated with drug development, patent protection in the pharmaceutical industry is necessary. Public acceptance is much lower when it comes to release of genetically modified organisms or genetically engineered food. Disquiet is widespread and the activist's argument that genetic modification is just as invisible as radioactive contamination quickly transforms worry into fear.

The initiative's opponents argue that implementing the amendment would blunt the edge of the Swiss biotechnology and threaten a large number of jobs in the pharmaceutical industry. Similar arguments have begun to sway public attitudes in neighbouring Germany where, faced with an unemployment rate of more than $10 \%$, political support for the anti-technology-oriented parties and activist groups has weakened considerably. The Swiss too appear sensitive to job loss, having just voted "no" on a proposal to ban export of all industrial goods that could be used to manufacture weapons, a law that would have endangered at least 20,000 jobs.

Certainly, things have become more complex since the slaughter referendum in 1893. It would be a shame, however, if the vote next year were to reflect the balance between fear of potential genetic catastrophes on one hand, and economical arguments about jobs and tax money on the other. In a direct democracy, education of the public is essential. Given the increasing importance of genetics and biotechnology worldwide it is imperative that all societies invest in creating an educated population that can understand the benefits and risks associated with those technologies. It is only then that the debate can take place on a rational level. 